\title{
The analysis of price formula differences
}

\author{
J.J. Doppegieter and I.J. Lambrechts \\ Departement Bedryfsekonomie, Universiteit van Stellenbosch, Stellenbosch
}

In this article, the third in a series of four, accent has been placed on a dynamic analysis of differences between the two price formulae introduced and discussed in the first article. Four different formulae components were analysed by comparing the resulting incremental changes of the internal rates of return for the two price formulae. It appeared that the substantial differences between the internal rates of return of the two formulae, identified in the previous article, are mainly a function of two formulae components, i.e. the valuation method of fixed assets and the profitability rate allowed. The method of analysis, presented in this article, could be a meaningful means of analysing alternative formula components and selecting and defining a viable financial policy.

S. Afr. J. Bus. Mgmt. 1985, 16: $125-127$

In hierdie artikel, die derde in 'n reeks van vier, is die klem geplaas op 'n dinamiese analise van verskille tussen die twee formules wat in die eerste artikel bekendgostel en bespreek is. Vier verskillende formulekomponente is ondersoek deur die gevolglike inkrementele veranderings in die interne rentabiliteite van die twee formules te vergelyk. Dit het geblyk dat die aansienlike verskille tussen die interne rentabiliteite van die twee formules, soos geïdentifiseer in die vorige artikel, hoofsaaklik 'n funksie is van twee formulekomponente, naamlik die waardasiemetode van die vaste bates en die toegelate rentabiliteit. Die metode van ontleding wat in hierdie artikel toegepas is, kan betekenisvol wees in die ontleding van alternatiewe formulekomponente en die seleksie van 'n optimale finansiële beleid.

S.Afr. Tydskr. Bedryfsl. 1985, 16: 125- 127

J.J. Doppegieter* en I.J. Lambrechts

Departemeit Bedryfsekonomie, Universiteit van Stellenbosch,

Stellenbosch, 7600 Republiek van Suid-Afrika

*To whom correspondence should be addressed

\section{Introduction}

This article, the third in a series of four, presents a more meaningful method of analysing price formulae than methods presently in use. In an analysis of ten price formulae as applied in terms of the Price Control Act, it was shown that the formulae concerned differed for virtually every product/ service (see the first article in this series). It was shown that the formulae took into consideration a variety of different stipulations such as methods of valuation, allowances and ratios, with the result that it is difficult to compare the financial consequences of each.

Using conventional and/or intuitive methods of analysis, it is difficult to get a meaningful indication of the financial effect of implementing different formula prescriptions on the short and long-term company return. There are several reasons for this. Firstly, conventional methods are based on criteria (such as the accounting rate of return) which have a number of shortcomings. Secondly, conventional and intuitive methods are not sufficiently in tune with the complicated financial nature and the dynamic interrelations of especially large undertakings.

Hence, the purpose of this article is to present a more meaningful method of analysis.

\section{Method}

The basic method of analysis will be demonstrated by using data obtained by implementing four different formula prescriptions in the computer model described in the first article. The data were analysed by comparing the incremental differences in the internal rate of return of the companies involved.

In the first article four differences between formulae $\mathrm{A}$ and B were identified inter alia in respect of:

(i) The valuation method of fixed assets

(ii) The profit on additional cash allowed

(iii) The profitability rate allowed

(iv) The calculation of the additional depreciation.

Table 1 A comparison of the internal rates of retum (i.r.r.) of companies $A$ and $B$

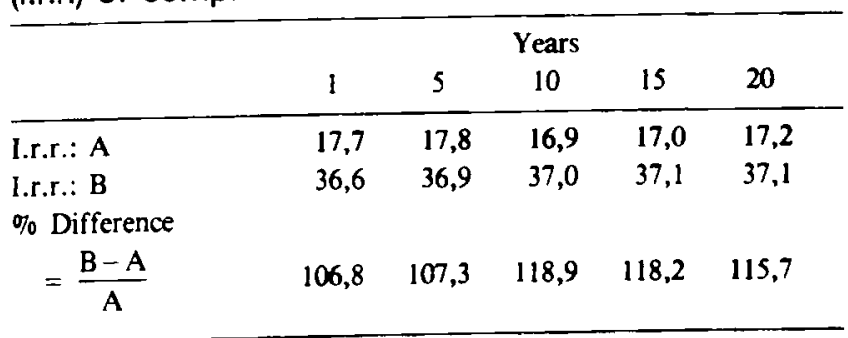


Since the foremost explanation for the significant differences in the internal rates of return of companies $A$ and $B$ (Table 1) is the variations between formulae A and B, the percentage differences must be mainly the result of the four different formula prescriptions.

\section{Results of the research}

In Table 2 the four different prescriptions, originating from formula $B$, and their effect on the internal rate of return of company A (they have been applied to model A) are shown. In the remainder of this article the data on each prescription will be illustrated and discussed briefly. The percentages in Table 2 are not directly comparable to those in Table 1 because all the differences in the formulae are not analysed.

Table 2 The effect of the four different prescriptions, originating from formula $\mathrm{B}$, on the internal rate of return of company $\mathrm{A}$

\begin{tabular}{lrrrrrr}
\hline & \multicolumn{5}{c}{$\begin{array}{c}\text { \% Change I.r.r. } \\
\text { Company A in year: }\end{array}$} \\
\cline { 2 - 7 } Changed prescription & 1 & 5 & 10 & 15 & 20 \\
\hline $\begin{array}{l}\text { The method of valuation of } \\
\text { fixed assets }\end{array}$ & 71,2 & 60,7 & 58,0 & 53,5 & 50,6 \\
$\begin{array}{l}\text { Exclusion of profit on additional } \\
\text { cash allowed }\end{array}$ & $-4,5$ & $-2,2$ & $-2,4$ & $-2,4$ & $-2,3$ \\
$\begin{array}{l}\text { The profitability rate allowed } \\
\text { The calculation of additional } \\
\text { depreciation }\end{array}$ & 79,1 & 41,8 & 43,8 & 42,9 & 41,9 \\
\hline & 0,6 & 1,7 & 3,6 & 4,7 & 4,7 \\
\hline
\end{tabular}

\section{Changing the method of valuation of fixed assets}

In company $\mathbf{A}$ the fixed assets are valued at historical cost whereas the new prescription, originating from formula $B$, provides for the valuation of fixed assets at replacement cost.

The implementation of this formula prescription has a positive effect on the internal rate of return of company A. The internal rate of return increases by $71,2 \%$ in year 1 , whereas the percentage increase decreases as a function of time, declining to $50,6 \%$ in year 20 (see Figure 1).

The new valuation method has a significant effect on the internal rate of return of company $A$. The new prescription explains nearly half of the difference between the two companies' original internal rates of return (see Tables 1 and 2). Figure 1 shows that, owing to the new method of valuation, the internal rate of return is at its maximum in the early years,

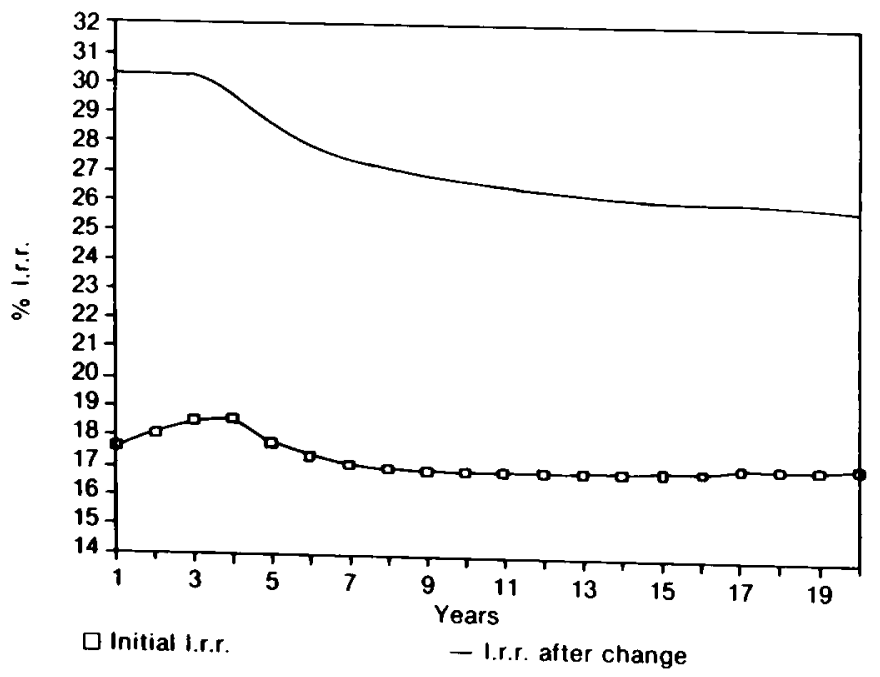

Figure 1 The effect of changing the valuation method of fixed assets on the internal rate of return (i.r.r.) of company $A$. after which it decreases gradually.

The explanation for the significant increase in return is clear. Unlike the original valuation method, valuation at replacement value provides, especially in times of higher inflation (presumed here to be $14 \%$ ), for a higher valuation of fixed assets and consequently a higher income and cash flow.

\section{Income on additional cash}

In contrast with formula $\mathrm{A}$, formula $\mathrm{B}$ does not include a provision for income on additional cash.

The exclusion of this prescription for company $\mathrm{A}$ has a small negative effect on the internal rate of return. However, Figure 2 shows that the negative effect decreases in time from $-4,5 \%$ in year 1 to $-2,3 \%$ in year 20 .

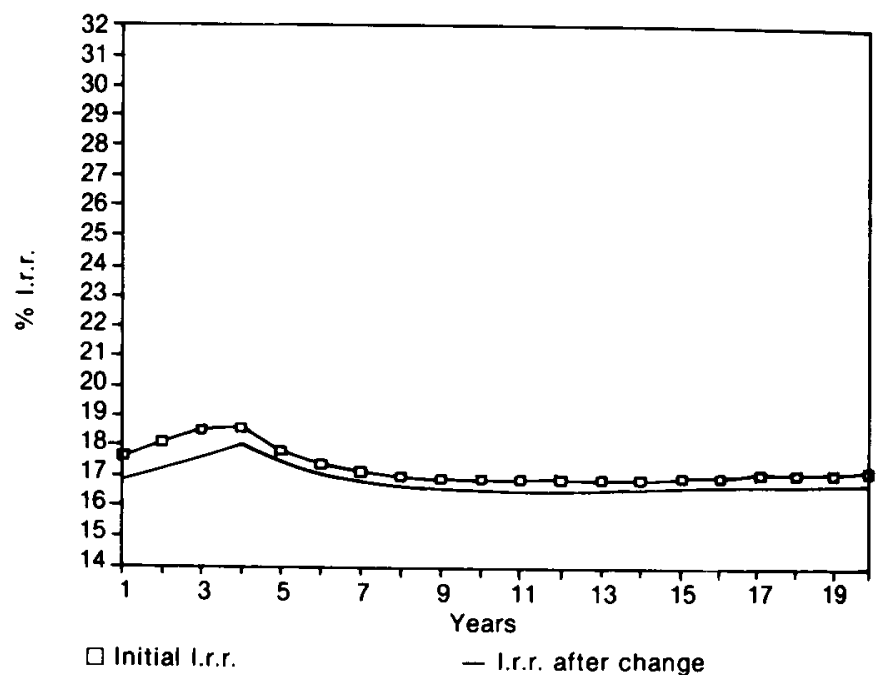

Figure 2 The effect of excluding income on additional cash allowed on the internal rate of return (i.r.r.) of company $A$.

\section{The profitability rate allowed}

The profitability rate prescribed in formula $A$ is $15 \%$ on a before-tax basis compared with $15 \%$ on an after-tax basis in formula B. The $15 \%$ after tax corresponds to about $28 \%$ before tax with a tax rate of $46 \%$.

The implementation of a profitability rate on an after-tax basis has a strong positive effect on the internal rate of return of company $A$. In year 1 the internal rate of return increases by $79,1 \%$. Over time, however, the increase diminishes,

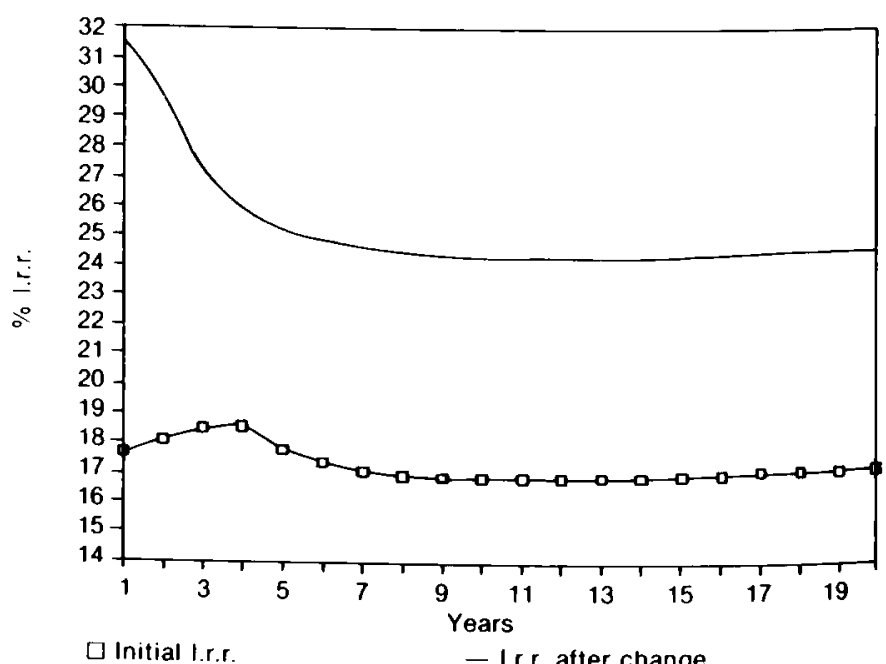

Figure 3 The effect of implementing the profitability rate on an aftertax basis on the internal rate of return (i.r.r.) of company $A$. 
becoming $41,9 \%$ in year 20 (see Figure 3).

The new profitability rate regulation appears to have a dramatic effect on the internal rate of return of company $A$. The reason for this is obvious. The higher profitability rate allowed provides for a higher 'base return allowed', an improved cash flow and, ultimately, a higher return.

\section{Inclusion of a tax adjustment for additional} depreciation

Formula B offers a tax provision in respect of additional depreciation to provide for the non-deductibility of additional depreciation, which is not found in formula $A$.

Implementing the tax adjustment in the model for company A has a positive effect on the internal rate of return of that company. The internal rate of return increases by between $0,6 \%$ in year 1 and 4,7\% in year 20 (see Figure 4).

It is clear that including a tax adjustment for additional depreciation should have a positive effect on the internal rate of return since additional cash flow would be generated. The

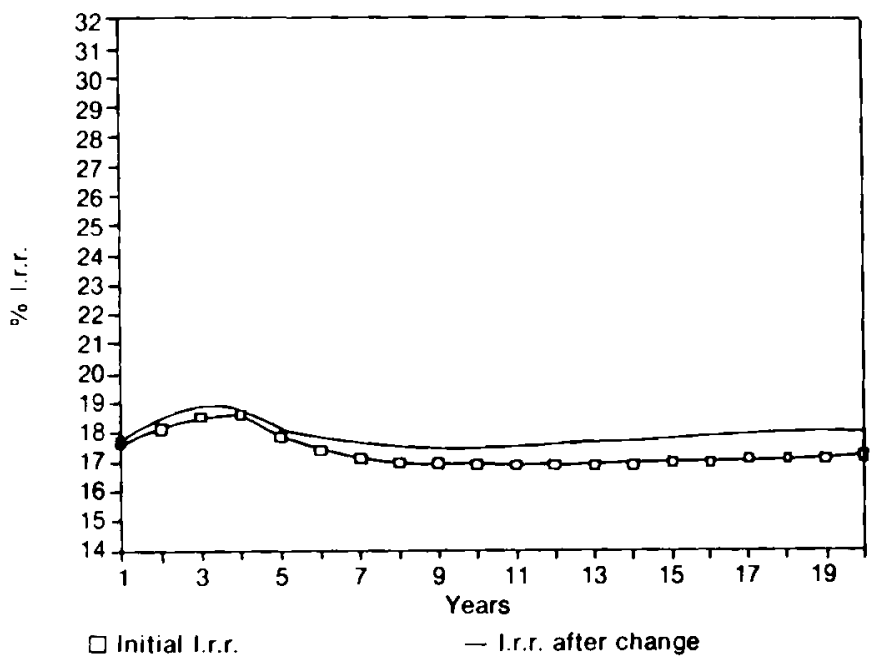

Figure 4 The effect of including a tax deduction for additional depreciation on the internal rate of return of company $\mathbf{A}$. implementation of the tax adjustment for additional depreciation, however, has no marked influence on the internal rate of return of company A. This is especially so when the result is compared to that of changing the method of valuation of fixed assets and changing the profitability rate allowed. It is interesting to note that the effect on the internal rate of return increases over time.

\section{Further applications of the analysis method}

Having developed the model, the method of analysis of the four alternative formula prescriptions described in this article can be extended relatively easily to accommodate additional applications.

Firstly, combinations of alternative formula prescriptions could be analysed. Secondly, the various alternative formula prescriptions can be examined in another way by quantifying their effects in terms of other criteria, e.g. the effect of implementing alternative prescriptions on the ratio equity: total capital employed. Finally, the model can be used to simulate and analyse different types of alternative hypotheses to simplify the task of selecting and defining viable company strategies, e.g.

- dividend policies

- growth strategies

- tax options.

\section{Summary and conclusions}

In this third article accent has been placed on the simulation and analysis of four different formula prescriptions. It appeared that the substantial differences between the internal rates of return of companies $\mathrm{A}$ and $\mathrm{B}$ are mainly the result of

- the valuation method of fixed assets, and

- the profitability rate allowed.

The method of analysis presented in this article would be a meaningful means of simulating, analysing and evaluating different formula prescriptions. It is believed that this method could be of value to all bodies, corporations, companies and institutions in determining and evaluating selling prices. 